\title{
THE IMPLEMENTATION OF PUBLIC SERVICE IN GENERAL HOSPITAL OF SUKABUMI CITY, WEST JAVA
}

\author{
Ni Putu Juwanita Dewi \\ 1)R. Syamsudin, SH General Hospital, Sukabumi West Java, Indonesia \\ 2) Law College of Pasundan, Sukabumi, West Java, Indonesia
}

\begin{abstract}
Background: A hospital is a facility to provide a health service which is primarily give access to curative health. The demands of the public for better services is a need that must be met by government agencies that provide health services. This study aimed to observe the implementation of public service in general hospital of Sukabumi City West Java.

Subjects and Method: This study used a qualitative method using a frame of mind from Edward III's Policy Theory. The data were conducted by enrolled a tot al of 16 informants. Data were collected through in-depth interviews, observation, and review of documents related to public services at general hospital of Sukabumi city. The data were analyzed descriptively.

Results: In this study, the implementation of public services at the general hospital of Sukabumi City had been running well but was not optimal and required improvement in several aspects. There is a need of regular meetings to discuss the implementation of public services, monitoring and evaluation by the board of directors, communication training for hospital staff, especially employees who deal directly with patients and / or patients' families, repair, improvement of public facilities at the Sukabumi City Hospital, and there should be a special department to coordinate the implementation of public services.

Conclusion: The implementation of public services at the general hospital of Sukabumi City has been running well. The optimalization and improvement are needed for this hospital.
\end{abstract}

Keywords: implementation, public service, hospital

\section{Correspondence:}

Ni Putu Juwanita Dewi. RSUD R. Syamsudin, SH General Hospital, Sukabumi, Law College of Pasundan, Sukabumi, 43313, West Java, Indonesia.

Email: happynitadewi@gmail.com. Mobile Phone: +62817438713 